\title{
Current Treatment Options for Metastatic Pancreatic Adenocarcinoma
}

\author{
Mehmet AN SENDUR ${ }^{1}$, Ozan YAZICI ${ }^{2}$, Nuriye Y. OZDEMIR ${ }^{1}$, Sercan AKSOY ${ }^{3}$ \\ ${ }^{1}$ Yıldırım Beyazıt University, Faculty of Medicine, Department of Medical Oncology \\ ${ }^{2}$ Ankara Numune Training and Research Hospital, Department of Medical Oncology \\ ${ }^{3}$ Hacettepe University, Cancer Institute, Department of Medical Oncology, Ankara, TURKEY
}

\begin{abstract}
Pancreatic adenocarcinoma is the fourth leading cause of cancer-related death and have extremely poor prognosis. Although, declining trends for some major cancers, death rates are rising in both sexes for pancreatic cancer. Surgical resection is the only curative treatment of pancreatic cancer, but only 10 to 20 percent of patients are candidates for curative surgery. Fifty to sixty percent of patients with pancreatic cancer diagnosed in metastatic stage and 5-year overall survival (OS) rate is less than 5\% for metastatic pancreatic cancer. Gemcitabine was the first chemotherapeutic agent that superior to 5-Fluorouracil. In most of the phase II trials combination gemcitabine with cytotoxic chemotherapy or targeted therapy showed promising results, but phase III trials with gemcitabine in combination with cisplatin, oxaliplatin, capacitabine, pemetrexed, irinotecan, bevacizumab, aflibercept, axitinib and cetuximab failed to improve primary endpoint OS. Monotherapy with S-1 demonstrated noninferiority to gemcitabine in OS and S-1 approved for pancreatic cancer in Japan. In a randomized phase II/III ACCORD trial median progression free survival (PFS), response rate (RR), median OS and quality of life were significantly prolonged in FOLFIRINOX arm compared to gemcitabine alone arm. In phase III (MPACT) trial, like FOLFIRINOX regimen, median PFS, RR and OS significantly prolonged with the combination nab-paclitaxel and gemcitabine compared to gemcitabine arm alone. As a targeted agent erlotinib is the first and only agent that demostrate signifiacnt activity with gemcitabine combination in patients with metastatic pancreatic cancer. Gemcitabine plus erlotinib combination significantly prolonged PFS and OS compared to gemcitabine alone arm. Although some combination regimens showed significant OS benefit compared to single-agent gemcitabine, the median OS was less than 1 year. On these grounds, future directions are needed to integrate new targeted agents and combination protocols for metastatic pancreatic cancer.
\end{abstract}

Keywords: Pancreatic cancer, Adenocarcinoma, Metastatic disease, Chemotherapy

ÖZET

\section{Metastatik Pankreatik Adenokanserinde Güncel Tedavi Seçenekleri}

Pankreas kanseri, kansere bağı ölümlerin en sık 4. sebebi olup, son derece kötü prognoza sahiptir. Çoğu önemli kanserinde son ylllarda mortalitede belirgin azalma olmasına rağmen, pankreas kanseri mortalitesinde her 2 cinsiyette de artış devam etmektedir. Cerrahi rezeksiyon tek küratif tedavi yaklaşımı olmasına rağmen, sadece hastaların \%10 ile \%20'si küratif cerrahiye adaydırlar. Pankreas kanseri tanısı konulan hastaların \%50-60'ı metastatik evrede tanı almaktadır ve 5 yıllık genel sağkalım (GS) \%5'in altındadır. Gemsitabin 5-Fluorourasil'e kıyasla GS ve progresyonsuz sağkalım (PFS) avantajı sağlayan ilk ajandır. Birçok faz II çalışmada gemsitabin ile diğer sitotoksik veya hedefe yönelik tedavi kombinasyonları ümit verse de faz III çalışmalarda gemsitabin ile sisplatin, oxaliplatin, kapasitabin, pemetrexed, irinotekan, bevasizumab, aflibercept, axitinib ve cetuximab kombinasyonları gemsitabin monoterapisine kıyasla GS faydası sağlamamıştır. Yapılan faz III çalışmada S-1 monoterapisinin gemsitabin monoterapisine GS açısından non-inferior olduğu saptanmış olup, S1 monoterapisi Japonya'da metastatik pankreas kanseri tedavisinde onay almıştır. Randomize faz II/III ACCORD çalışmasında ortanca PFS, yanıt oranı, GS ve yaşam kalitesi FOLFiRiNOX kombinasyon tedavisinde gemsitabin monoterapisine kıyasla anlamlı olarak artmıştır. Aynı şekilde faz III MPACT çalışmasında da FOLFiRiNOX çalışmasındakine benzer şekilde, gemsitabine-nabpaklitaxel kombinasyonu ile ortanca PFS, yanıt oranı, GS ve yaşam kalitesi tedavisinde gemsitabin monoterapisine kıyasla anlamlı olarak artmıştır. Metastatik pankreas kanserinde erlotinib gemsitabin ile kombinasyon tedavisinde gemsitabine kıyasla istatistiksel olarak anlamlı GS ve PFS avantajı gösteren ilk ve tek hedefe yönelik ajandır. Kombinasyon tedavilerinin son zamanlarda anlamlı GS avantajı göstermesine rağmen ortanca GS halen 1 ylın altındadır. Bu nedenle yeni hedefe yönelik ajanlara ve kombinasyon tedavilerine intiyaç duyulmaktadır.

Anahtar Kelimeler: Pankreas kanseri, Adenokarsinom, Metastatik hastalık, Kemoterapi 


\section{INTRODUCTION}

Pancreatic adenocarcinoma is the fourth leading cause of cancer-related death in United States and there were estimated 48.960 new cases of pancreatic adenocarcinoma in 2015 with an 40.560 estimated deaths. ${ }^{1}$ Although declining trends for some major cancers, death rates is still rising in both sexes for pancreatic cancer. Pancreatic adenocarcinoma is rarely diagnosed before 4 th decade and the median age of diagnosis is 71 years. ${ }^{1}$ Surgical resection is the only curative treatment of pancreatic cancer, but only 10 to 20 percent of patients are candidates for curative surgery. The prognosis of pancreatic cancer is still poor even in those with potentially resectable disease. Five-year overall survival (OS) rate following surgery is only about 10 to 20 percent whereas 5-year OS rate is less than $5 \%$ for metastatic pancreatic cancer. ${ }^{1}$ Patients with metastatic pancreatic cancer often are severely symptomatic and the primary aims of the treatments are palliation, improve quality of life and survival.

New therapeutic molecular targets are required to improve the survival of patients with metastatic pancreatic cancer. In this article, we review the currently available treatments in light of the most recent publications and guidelines, along with promising therapeutic options that are still under development for patients with advanced or metastatic pancreatic cancer.

\section{RESULTED PHASE III TRIALS FOR META- STATIC PANCREATIC CANCER}

\section{FIRST LINE CHEMOTHERAPY}

Most patients with metastatic pancreatic cancer experience severe pain, weight loss and multiple related symptoms that limit patients' daily activities. 5-Fluorouracil (5-FU) based chemotherapy was the first treatment strategy for metastatic pancreatic cancer. 5-FU based regimens improved survival approximately 3 months with less than $20 \%$ of response rate. As a single agent or in combination with other chemotherapeutics, 5-FU added limited survival benefit. ${ }^{2}$ After clinical benefit response
(CBR) benefit with gemcitabine in a phase II trial of patients with 5-FU-refractory pancreas cancer, gemcitabine was the first chemotherepautic agent that significantly improved clinical benefit and OS compared to $5-\mathrm{FU}^{3}$ In a randomized study, 126 advanced symptomatic pancreatic cancer patients were randomized 1:1 to receive either gemcitabine $1000 \mathrm{mg} / \mathrm{m}^{2}$ weekly for 7 weeks followed by 1 week of rest, then weekly for 3 weeks in every 4 weeks or to 5 -FU $600 \mathrm{mg} / \mathrm{m}^{2}$ once weekly. ${ }^{3}$ Clinical benefit response was the primary endpoint of this study and was significantly better in gemcitabine-treated patients compared to 5-FU-treated patients $(23.8 \%$ vs $4.8 \%, \mathrm{p}=0.002)$. Median OS also significantly prolonged in gemcitabine-treated patients compared to 5-FU-treated patients (5.65 vs 4.41 months, $\mathrm{p}=0.002$ ). One-year survival rates were $18 \%$ and $2 \%$ and disease stabilization was observed in 39\% and 19\% in gemcitabine-treated patients compared to 5-FU-treated patients, respectively., Both gemcitabine and 5-FU single-agent chemotherapeutics were generally well-tolerated and grade 3 and 4 neutropenia was reported in $25.9 \%$ and $4.9 \%$ of in gemcitabine and 5-FU-treated patients, respectively.

Phase I and II trials of single-agent S-1 (5-Fu derivative) resulted response rates up to 37 percent. $^{5}$ Thus S-1 was approved for metastatic pancreatic cancer in Japan. In phase III GEST (Gemcitabine and S-1 Trial) study, treatment-naive 834 patients with metastatic pancreatic cancer were randomized to receive only gemcitabine $\left(1.000 \mathrm{mg} / \mathrm{m}^{2}\right.$ weekly for three weeks in every 4 week), or only S-1 (80, 100 , or $120 \mathrm{mg}$ /day according to body-surface area for 28 days followed with 2 weeks rest) or gemcitabine plus S-1 (gemcitabine $1.000 \mathrm{mg} / \mathrm{m}^{2}$ on days 1 and 8 plus S-1 60,80 , or $100 \mathrm{mg} / \mathrm{d}$ according to body-surface area on days 1-14, every 3 weeks). ${ }^{6}$ Primary endpoint of the study was OS. Median OS was 8.8 months, 9.7 months and 10.1 months in the gemcitabine, $\mathrm{S}-1$ and gemcitabine plus $\mathrm{S}-1$ groups, respectively. Monotherapy with S-1 demonstrated non-inferiority to gemcitabine ( $\mathrm{HR}=0.96, \mathrm{p}<$ 0.001 for noninferiority) in overall survival but superiority of gemcitabine plus S-1 was not showed compared to gemcitabine alone arm (HR; $0.88, \mathrm{p}=$ $0.15)$. 


\section{Gemcitabine-Based Combinations}

Gemcitabine plus Cisplatin: Due to the significant survival benefit with single-agent gemcitabine chemotherapy compared to 5-FU, multiple randomized trials were aimed to compare the efficacy of gemcitabine combination therapies compared to single-agent gemcitabine therapy. In a prospective randomized phase III study from the Gruppo Oncologia dell'Italia Meridionale, 107 patients with locally advanced or metastatic pancreatic adenocarcinoma were randomized to gemcitabine 1000 $\mathrm{mg} / \mathrm{m}^{2}$ weekly for 7 weeks, followed with 2 weeks off, then treatment was resumed on days 1,8 , and 15 of a 28-day cycle for 2 cycles or in combination with cisplatin $25 \mathrm{mg} / \mathrm{m}^{2}$ weekly with the same dose of gemcitabine. ${ }^{7}$ The primary endpoints of this study were time to progression (TTP) and CBR. Median TTP was 8 and 20 weeks in gemcitabine alone and gemcitabine plus cisplatin combination arms, respectively $(\mathrm{p}=0.048)$. Objective response rate (ORR) was significantly prolonged in combination arm (26.4\% vs $9.2 \%, \mathrm{p}=0.02)$. The clinical benefit rate was similar in two arms and median OS was 20 and 30 weeks in gemcitabine alone and gemcitabine plus cisplatin combination arms, respectively $(\mathrm{p}=0.43)$.

In another randomized phase III trial, 195 patients with advanced pancreatic cancer were randomized to gemcitabine plus cisplatin or gemcitabine alone. ${ }^{8}$ Gemcitabine $1.000 \mathrm{mg} / \mathrm{m}^{2}$ and cisplatin $50 \mathrm{mg} / \mathrm{m}^{2}$ combination was given on 1 st and 15 th days in every 28 days or gemcitabine $1.000 \mathrm{mg} / \mathrm{m}^{2}$ weekly alone for three weeks followed with 1 week off. The primary endpoint was OS. Median progression free survival (PFS) was prolonged from 3.1 months to 5.3 months with gemcitabine plus cisplatin combination compared to gemcitabine alone $\operatorname{arm}(\mathrm{p}=0.053)$. In the subgroup analyses median PFS was significantly better with combination arm in locally advanced disease (8.6 vs 3.2 months, $\mathrm{p}=$ $0.005)$, whereas no significant advantage was reported in patients with metastatic disease (4.2 vs 3.1 months, $p=0.31$ ). Median OS was more favorable in combination arm but not significant (7.5 vs 6.0 months, $p=0.15)$. Median OS was significantly prolonged with combination arm in patients with metastatic disease only (7.2 vs 4.7 months), where- as no survival advantage was observed with combination treatment in locally advanced pancreatic cancer (10.3 vs 10.4 months). In subgroup analyses, patients with Karnofsky Performance Status (KPS) $90 \%$ to $100 \%$, median OS increased from 6.9 months to 10.7 months ( $\mathrm{p}=0.051$ ), but no survival improvement was seen in patients with KPS $70 \%$ to $80 \%$ (4.9 vs 4.8 months). Although, similar response rates were observed in two treatment arm, significantly greater rate of stable disease was achieved with gemcitabin plus cisplatin combination compared to single-agent gemcitabine alone $\operatorname{arm}(60.2 \%$ vs $40.2 \%, \mathrm{p}<0.001)$. Disease control rate (DCR) was also significantly favor combination $\operatorname{arm}(70.4 \%$ vs $49.5 \%, \mathrm{p}<0.001)$.

In randomized phase III GIP-1 (Gruppo Italiano Pancreas-1) trial, 400 patients with advanced pancreatic cancer were randomly assigned to gemcitabine $1,000 \mathrm{mg} / \mathrm{m}^{2}$ weekly for 7 weeks followed with 1 week off and after a 1 week rest treatment was resumed on days 1,8 , and 15 of a 28 -day cycle or cisplatin $25 \mathrm{mg} / \mathrm{m}^{2}$ added weekly to gemcitabine, except cycle 1 day $22 .{ }^{9}$ Primary end point of GIP1 trial was OS. Median OS was 8.3 months and 7.2 months in gemcitabine alone and gemcitabine plus cisplatin arms, respectively $(\mathrm{p}=0.38)$. Median PFS was 3.9 and 3.8 months in gemcitabine alone and gemcitabine plus cisplatin arms, respectively $(\mathrm{p}=0.80)$. The ORR was $10.1 \%$ in gemcitabine alone arm and $12.9 \%$ gemcitabine plus cisplatin $(p=0.37)$. In conclusion of this randomized controlled trials, the use of gemcitabine plus cisplatin combination in the treatment of advanced pancreatic cancer did not provide significant benefit compared to gemcitabine alone. Although, gemcitabine plus cisplatin combination failed to demostrate any survival improvement in first line treatment of advanced pancreatic cancer, selected patients may benefit from this combination. In a single-center retrospective review from Johns Hopkins University Hospital, the OS significantly prolonged with platinum-combination regimens in patients with a family history of breast, ovarian or pancreatic cancers and with family history of pancreatic cancer alone (22.9 vs 6.3 months, $\mathrm{p}<0.01)$ whereas no benefit was observed with platinum-based therapy in patients without a family history of cancer. ${ }^{10}$ The BRCA1 and BRCA2 proteins are involved in 
regulation of cellular proliferation by DNA damage repair thus patients with BRCA1 and BRCA2 mutation carriers with pancreatic cancer may have distinct biologic outcomes and may have better benefit with platinum-based treatments.

Gemcitabine plus Oxaliplatin: Due to the promising results with gemcitabin-oxaliplatin (GemOx) combination in patients with metastatic pancreatic cancer in the French Multidisciplinary Clinical Research Group in Oncology (GERCOR) phase II trial, 2 randomized phase III trials investigated the efficacy of GemOx regimen compared to gemcitabine alone. ${ }^{11-13}$ First randomized phase III trial that designed by both GERCOR and Italian Group for the Study of Gastrointestinal Tract Cancer (GISCAD), randomly assigned 313 patients with advanced pancreatic cancer to GemOx (gemcitabine $1000 \mathrm{mg} / \mathrm{m}^{2}$ plus oxaliplatin $100 \mathrm{mg} / \mathrm{m}^{2}$, every two weeks) or gemcitabine $\left(1000 \mathrm{mg} / \mathrm{m}^{2}\right.$ weekly) alone. ${ }^{12}$ Primary endpoint was OS. Although, response rate $(26.8 \%$ vs $17.3, \mathrm{p}=0.04)$, median PFS (5.8 months vs 3.7 months, $\mathrm{p}=0.04$ ) and CBR $(38.2 \%$ vs $26.9 \%, p=0.03)$ were significantly improved in GemOx arm compared to gemcitabine alone arm, no significant survival benefit was observed in Gemox arm compared to gemcitabine $\operatorname{arm}(9.0$ months vs 7.1 months, $\mathrm{p}=0.13)$. In another phase III Eastern Cooperative Oncology Group (ECOG) 6201 trial 832 patients with metastatic or locally advanced pancreatic cancer randomized to fixed-dose rate (FDR) gemcitabine $\left(1500 \mathrm{mg} / \mathrm{m}^{2}\right.$ weekly for three weeks followed with one week off) or standard weekly gemcitabine $(1000 \mathrm{mg} /$ $\mathrm{m}^{2}$ for three weeks followed with one week off) or GemOx (gemcitabine $1000 \mathrm{mg} / \mathrm{m}^{2}$ plus oxaliplatin $100 \mathrm{mg} / \mathrm{m}^{2}$ every two weeks). ${ }^{13}$ The primary endpoint was OS and the study was designed to to detect a $33 \%$ difference in median survival. No difference on OS and PFS was observed with FDRgemcitabine, GemOx and gemcitabine alone arms, respectively.

Gemcitabine plus Capecitabine: Preclinical and phase II studies showed that the combination of gemcitabine with capecitabine (GemCap) works synergistically in advanced pancreatic cancer pa- tients. Thus in two phase III trials, the efficacy of GemCap was tested. ${ }^{14,15}$ First Phase III Trial of the Swiss Group for Clinical Cancer Research and the Central European Cooperative Oncology Group randomly assigned 319 advanced pancreatic cancer patients to GemCap (oral capecitabine $650 \mathrm{mg} /$ $\mathrm{m}^{2}$ twice daily between 1-14 days plus gemcitabine $1.000 \mathrm{mg} / \mathrm{m}^{2}$ on days 1 and 8 every 3 weeks) or gemcitabine $\left(1000 \mathrm{mg} / \mathrm{m}^{2}\right)$ weekly for 7 weeks, followed 1-week rest, and then weekly for 3 weeks every 4 weeks. ${ }^{14}$ Primary endpoint was OS. Median OS was 8.4 and 7.2 months in the GemCap and gemcitabine arms, respectively $(\mathrm{p}=0.234)$. In subgroup analyses, patients with KPS $90 \%$ to $100 \%$, median OS increased from 7.4 months to 10.1 months $(\mathrm{p}=0.014)$ with GemCap combination whereas for patients with a KPS $60 \%$ to $80 \%$, median OS was 5.3 months for GemCap and 7.0 months for gemcitabine ( $\mathrm{p}=0.231)$. Median PFS was 4.3 and 3.9 months in GemCap and gemcitabine alone arms, respectively ( $\mathrm{p}=0.103)$. As like OS, median PFS was significantly better in GemCap arm in patients with good performance status $(\mathrm{p}=0.022)$. In another randomized phase III trial, 533 advanced pancreatic cancer patients randomly assigned to gemcitabine $\left(1000 \mathrm{mg} / \mathrm{m}^{2}\right)$ weekly for 7 weeks, followed 1-week rest, and then weekly for 3 weeks every 4 weeks or GemCap (oral capecitabine $830 \mathrm{mg} / \mathrm{m}^{2}$ twice daily between 1-21 days plus gemcitabine $1000 \mathrm{mg} / \mathrm{m}^{2}$ weekly for 3 weeks then 1 week off, every 4 weeks). 15 Primary endpoint was OS. In GemCap arm, ORR (19.1\% vs $12.4 \%, \mathrm{p}=0.034)$ and median PFS (5.3 months vs 3.8 months, $p=0.004$ ) were significantly improved compared to gemcitabine alone arm whereas trend for improved OS (7.1 months vs 6.2 months, $\mathrm{p}=$ 0.08 ) in combination arm.

Gemcitabine plus Nab-Paclitaxel: Albuminbound paclitaxel (nab-paclitaxel) showed antitumor activity as a single agent and synergistic activity in combination with gemcitabine in preclinical and phase I and II studies. Nab-paclitaxel, nonotechnology used to combine human albumin and paclitaxel, increases the delivery of nanoparticles to the tumor and enhance the efficacy of paclitaxel. In addition to nab-paclitaxel potentiates gemcitabine activity by reducing cytidine deaminase lev- 
els in a mouse model of pancreatic cancer. ${ }^{16}$ In a phase I/II trial of gemcitabine plus nab-paclitaxel median OS was 12.2 months and response rate was $48.0 \% .{ }^{17}$ In phase III (MPACT) trial, 861 patients with metastatic pancreatic cancer were randomized to gemcitabine $\left(1000 \mathrm{mg} / \mathrm{m}^{2}\right)$ plus nab-paclitaxel $\left(125 \mathrm{mg} / \mathrm{m}^{2}\right)$ weekly for three weeks followed with one week rest or gemcitabine $\left(1000 \mathrm{mg} / \mathrm{m}^{2}\right)$ monotherapy weekly for 7 weeks followed with 1 -week rest and then weekly for three weeks followed with one week rest until progression.18 The primary end point was OS. Median PFS (5.5 vs 3.7 months, $\mathrm{p}<0.001)$, response rate $(23 \%$ vs $7.0 \%$, $\mathrm{p}<0.001)$ and median OS (8.5 vs 6.7 months, $\mathrm{p}<$ $0.001)$ were significantly prolonged with the combination gemcitabine plus nab-paclitaxel compared to gemcitabine alone arm. One-year survival rate was $35 \%$ and $22.0 \%$, 2-year survival rate was $9.0 \%$ and $4.0 \%$ in gemcitabine plus nab-paclitaxel and single-agent gemcitabine arms respectively. Most common reported grade 3-5 adverse events with combination were neutropenia $(38.0 \%)$, fatigue $(17.0 \%)$, neuropathy $(17.0 \%)$ and trombocytopenia $(13.0 \%)$. Due to the significant OS benefit with nab-paclitaxel plus gemcitabine, nab-paclitaxel approved for the treatment of first line treatment of metastatic pancreatic cancer.

\section{FOLFIRINOX (Fluorouracil, Leucovorin,}

Irinotecan, Oxaliplatin): Preclinical studies showed that irinotecan and oxaliplatin have synergistic activity with each other and in combination with fluorouracil and leucovorin. Phase 1 and phase II trials showed that FOLFIRINOX regimen was associated with benefit nearly half of the patients. ${ }^{19,20}$ In a randomized phase II/III ACCORD trial 342 patients with metastatic pancreatic cancer were randomized to receive FOLFIRINOX (oxaliplatin, $85 \mathrm{mg} / \mathrm{m}^{2}$; irinotecan, $180 \mathrm{mg} / \mathrm{m}^{2}$; leucovorin, $400 \mathrm{mg} / \mathrm{m}^{2}$; and fluorouracil, $400 \mathrm{mg}$ / $\mathrm{m}^{2}$ bolus followed with $2400 \mathrm{mg} / \mathrm{m}^{2}$ 46-hour continuous infusion, every 2 weeks) or gemcitabine $\left(1000 \mathrm{mg} / \mathrm{m}^{2}\right)$ monotherapy weekly for 7 weeks followed with 1-week rest and then weekly for three weeks followed with one week rest up to 6 months. ${ }^{21}$ The primary end point was OS. Median PFS (6.8 vs 3.1 months, $\mathrm{p}<0.001$ ), response rate (31.6\% vs $9.4 \%, \mathrm{p}<0.001)$ and median OS $(11.1$ vs 6.8 months, $\mathrm{p}<0.001)$ were significantly prolonged in FOLFIRINOX arm. According to the quality of life measurements; $31 \%$ of the patients in the FOLFIRINOX group and 66\% in the gemcitabine group had a definitive decrease in the scores on the Global Health Status and Quality Life scale at 6 months $(\mathrm{p}<0.001)$. Grade 3-4 neutropenia, febrile neutropenia, thrombocytopenia, diarrhea, and sensory neuropathy were significantly higher in the FOLFIRINOX group. Febrile neutropenia was reported in $5.4 \%$ of patients treated with FOLFIRINOX.

Gemcitabine with other Combinations: Although phase I and II studies showed that irinotecan had similar benefit as gemcitabine in treatment-naive metastatic pancreatic cancer and showed synergistic activity with combination of gemcitabine, in two phase III trials gemcitabine plus irinotecan combination did not improve median PFS and OS. ${ }^{22,23}$ Preclinical and phase I-II studies showed synergy with gemcitabine plus pemetrexed combination. ${ }^{24,25}$ In phase III trial of pemetrexed plus gemcitabine versus gemcitabine in patients with unresectable or metastatic pancreatic cancer no significant PFS and OS benefit was observed with combination arm. $^{26}$ In conclusion gemcitabine comibination with irinotecan or pemetrexed did not improve the primary endpoint but both regimens only improved response rate.

First-line Targeted Agents: Epidermal growth factor receptor (EGFR) was over-expressed in most of the pancreatic cancers and preclinical studies showed that EGFR inhibition decreases the growth and metastasis of human pancreatic tumor xenografts and increased the efficacy and anticancer effects of gemcitabine. ${ }^{27}$ A phase III, double blind trial from the National Cancer Institute of Canada Clinical Trials Group randomized 569 patients with metastatic pancreatic cancer to standard gemcitabine plus erlotinib (oral HER1/EGFR tyrosine kinase inhibitor, 100 or $150 \mathrm{mg} / \mathrm{d}$ ) or gemcitabine plus placebo. ${ }^{28}$ The primary end point was OS Median PFS (3.75 vs 3.55 months, $p=0.004)$ and median OS (6.24 vs 5.91 months, $\mathrm{p}=0.038$ ) were significantly longer in gemcitabine plus erlotinib 
arms, respectively. One-year survival rates were $23 \%$ and $17 \%$, respectively $(\mathrm{p}=0.023)$. Overall disease control rates $(57.5 \%$ and $49.2 \%)$ and ORR $(8.6 \%$ vs $8.0 \%)$ were not significant between treatment arms. Erlotinib is the first agent demonstrated significant activity with gemcitabine combination in patients with metastatic pancreatic cancer. ${ }^{28}$

Due to the clinical benefit of anti-EGFR treatment was shown, the benefit of another monoclonal antibody cetuximab, against the ligand-binding domain of EGFR receptor, was tested in a phase III Southwest Oncology Group-Directed Intergroup Trial S0205..$^{29}$ In this trial 745 patients with unresectable locally advanced or metastatic pancreatic adenocarcinoma were randomized to gemcitabine alone or gemcitabine plus cetuximab. The primary endpoint was OS. Median OS was 5.9 months in gemcitabine alone arm and 6.3 months in gemcitabine plus cetuximab arm $(\mathrm{p}=0.23)$. Median PFS and ORR were also similar in both treatment arms whereas only time to treatment failure significantly improved with gemcitabine plus cetuximab arm $(p=0.006)$. In conclusion, adding cetuximab to gemcitabine did not improve the outcome compared with patients treated with gemcitabine alone.

Although phase II trial showed promising response rate and median 8.8 months survival with adding bevacizumab to gemcitabine, in phase III trial of the Cancer and Leukemia Group B (CALGB 80303) adding bevacizumab to gemcitabine did not improve the primary endpoint OS and PFS and ORR compared to gemcitabine alone in patients with advanced pancreatic cancer. ${ }^{30}$ Like adding bevacizumab, adding vascular endothelial growth factor (VEGF) receptors 1, 2, and 3 tyrosine kinase inhibitor axitinib to gemcitabine improved OS significantly compared to gemcitabine alone in a randomized phase II trial, whereas in a double-blind, phase 3 trial did not show benefit in the primary endpoint OS and the secondary endpoint PFS with the addition of axitinib to gemcitabine compared to gemcitabine alone arm. ${ }^{31}$ In another phase III trial the efficacy of adding aflibercept to gemcitabine was investigated in patients with advanced pancreatic cancer. ${ }^{32}$ This study was stopped for futility after interim analysis of OS in 427 randomized patients because median OS was 7.8 months in gem- citabine plus placebo arm whereas 6.5 months in gemcitabine plus aflibercept $(\mathrm{p}=0.20)$.

Phase III studies that both meet and not meet of the primary endpoint were summarized in Table 1.

\section{SECOND LINE CHEMOTHERAPY}

OFF or FOLFOX: Approximately half of the patients were progressed after first-line therapy. A fluoropyrimide combination therapy was recommended as second-line therapy to patients progressed after gemcitabine based first-line therapy. In phase II trials, oxaliplatin was demonstrated to be effective chemotherapy agent as second line therapy in patients with metastatic pancreas cancer. ${ }^{33}$ In a phase III trial, the patients with metastatic pancreas cancer who were progressed after first line gemcitabine based regimen, were randomized 1:1 to receive oxaliplatin, folinic acid and 5-FU (OFF) or best supportive care (BSC). OFF regimen consisted of folinic acid $200 \mathrm{mg} / \mathrm{m}^{2}$ followed by 5 -fluorouracil $2 \mathrm{~g} / \mathrm{m}^{2}$ (24h) on day 1, day 8 , day 15 , day 22 and oxaliplatin $85 \mathrm{mg} / \mathrm{m}^{2}$ on days 8 and 22. After rest of 3 weeks the following cycle was initiated. A total of 165 patients were planned to enroll. However, after inclusion of 46 patients, the study was terminated early due to insufficient accrual rate. Although early termination, patient characteristics were well balanced between study arms. Median second-line OS for OFF and BSC arm was 4.82 [95\% CI; 4.29-5.35] and 2.30 [95\% CI; 1.76-2.83] months, respectively $(0.45$ [95\% CI: $0.24-0.83], \mathrm{p}=0.008)$. The OFF regimen was well tolerated. As excepted, grade I/II paraesthesia and grade II/III nausea/emesis and diarrhea was observed significantly higher in OFF arm compared to BSC arm. The median OS until time of diagnosis (gemcitabine followed OFF) was 9.09 [95\% CI: 6.97-11.21] months compared to 7.90 [95\% CI: 4.95-10.84] months for gemcitabine followed by BSC ( 0.50 [95\% CI: 0.27-0.95], $\mathrm{p}=0.031)$. This phase III trial showed the first data that OFF regimen improved the OS in patients with metastatic pancreas cancer who were failed after first line gemcitabine based regimen. ${ }^{34}$ Recently, outcome from CONKO-003 trial was published. This was randomized and open label study which was con- 
ducted in 16 centers around Germany. The patients with metastatic pancreas cancer failed during first line gemcitabine monotherapy were randomized to receive folinic acid and fluorouracil (FF) or OFF. FF regimen consisted of folinic acid $200 \mathrm{mg} / \mathrm{m}^{2}$ followed by a continuous infusion of fluorouracil $2.000 \mathrm{mg} / \mathrm{m}^{2}$ over 24 hours on days $1,8,15$, and 22. OFF consisted of FF and oxaliplatin $85 \mathrm{mg} / \mathrm{m}^{2}$ administered before FF on days 8 and 22. A total of 168 patients were randomized to study arms. Of them 160 were eligible for primary analysis. At final data analysis time 155 patients were died. The median follow up time was 54.1 months. Patients received OFF had significantly longer median duration of OS (5.9 months; 95\% CI, 4.1 to 7.4) compared to patients received FF alone (3.3 months; 95\% CI, 2.7 to 4.0; comparison: HR, 0.66; 95\% CI, 0.48 to 0.91 ; log-rank $\mathrm{p}=0.010$ ). The median PFS was 2.9 months (95\% CI, 2.4 to 3.2) in OFF arm compared with 2.0 months ( $95 \%$ CI, 1.6 to 2.3 ) in FF arm (HR:0.68; 95\% CI, 0.50 to 0.94 ; log-rank $\mathrm{p}=0.019)$. In OFF arm grade $1 / 2$ neurotoxicity was observed more frequently $(n=29 ; 38.2 \%)$ compared with FF arm $(n=6 ; 7.1 \%)(\mathrm{p}<0.001)$. The other side effects were similar in between groups. Second line OFF chemotherapy regimen was significantly improved OS and PFS in patients with metastatic pancreas cancer who were progressed during first-line gemcitabine monotherapy. ${ }^{35}$ After the positive results of these trials, the NCCN Guidelines recommends fluropyrimidine plus oxaliplatin as a second-line treatment option. Although these trials used the OFF regimen most of the clinicians used the FOLFOX (oxaliplatin $85 \mathrm{mg} / \mathrm{m}^{2}$ on day $1,5-F U ~ 400 \mathrm{mg} / \mathrm{m}^{2} \mathrm{IV}$ on day 1 followed by 2400 $\mathrm{mg} / \mathrm{m}^{2}$ continuous infusion over 46 hours, and leucovorin $400 \mathrm{mg} / \mathrm{m}^{2} \mathrm{IV}$ on day 1 repeated every 14 days) regimen as a second line therapy. However, the results of the open label phase III PANCREOX trial did not showed the efficacy of addition of oxaliplatin to 5-FU based regimen. Furthermore, the addition of oxaliplatin to 5-FU plus leucoverin regimen had detrimental effect. In this trial 108 patients with advanced pancreas cancer failed after first line gemcitabine based treatment, were randomized to receive modified FOLFOX6 regimen or infusional 5-FU plus leucovorin. The median PFS was similar in both treatment arms (3.1 months vs
2.9 months, $\mathrm{p}=0.99$ ). The median OS was shorter in mFOLFOX6 arm compared to 5-FU plus leucovorin arm (6.1 vs 9.9 months, $p=0.02$ ). Grade $3 / 4$ adverse events were observed more frequently in FOLFOX arm (63\% vs $11 \%) .{ }^{36}$

Pemetrexed: In a phase II trial pemetrexed was evaluated in patients with advanced pancreas cancer who were failed after gemcitabine alone or gemcitabine based combinations. The patients were received pemetrexed $500 \mathrm{mg} / \mathrm{m}^{2}$ every 3 weeks until disease progression or occurrence of unacceptable toxicity. A total 52 patients were included in study population. The overall response rate was 3.8\% (two partial responses); 10 patients $(19.2 \%)$ had stable disease. The median PFS was 7 weeks (range 1-62 weeks) and the median OS was 20 weeks (range 1-84 weeks). The hematological toxicities were; neutropenia (17.3\%), thrombocytopenia $(5.8 \%)$ and anemia $(3.8 \%)$. The most frequent non-hematological toxic effects were diarrhea $(23.1 \%)$, nausea $(23.1 \%)$ and stomatitis $(23.1 \%)$. As a second line therapy pemetrexed was a safe treatment option with modest activity. ${ }^{37}$

Paclitaxel: In another phase II trial weekly paclitaxel was evaluated as a second line therapy in patients with good clinical condition after failure of gemcitabine therapy. Eighteen patients were enrolled to study. Paclitaxel was administered at weekly intervals. The median dosage was $73 \mathrm{mg} /$ $\mathrm{m}^{2}$ paclitaxel (range $55-88 \mathrm{mg} / \mathrm{m}^{2}$ ). The median OS was 17.5 weeks (range 7-88 weeks) since the start of therapy. Higher grade toxicities were rare, except alopecia. The weekly paclitaxel after failure of first line gemcitabine based therapies might be effective with tolerable toxicity profiles. ${ }^{38}$

Capecitabine: In a phase II trial, after failure of first line gemcitabine based chemotherapy oral capecitabine monotherapy was used as second line therapy. Capecitabine was administered orally at a dose of $1.250 \mathrm{mg} / \mathrm{m}^{2}$ twice daily for 14 days followed by 7 days of rest. Thirty nine patients were enrolled to study. Median PFS and OS was 2.3 months (range 
0.5-45.1) and 7.6 months (range 0.7-45.1), respectively. The most common toxicities were hand-foot syndrome (28\%); anemia (23\%); leg edema (15\%); diarrhea (13\%); nausea/vomiting (10\%), and leukocytopenia (10\%). Single agent capecitbaine is a safe second line treatment choice in patients with metastatic pancreas cancer failed after gemcitabine based therapy. ${ }^{39}$

Nano-Liposomal Irinotecan: In NAPOLI-1 trial, gemcitabine refractory patients with pancreas cancer were randomized to receive MM-398 (nano-liposomal irinotecan) $120 \mathrm{mg} / \mathrm{m}^{2}$ IV every 3 weeks or 5 -FU $2000 \mathrm{mg} / \mathrm{m}^{2}$ IV over 24 hours with leucovorin $200 \mathrm{mg} / \mathrm{m}^{2}$ weekly for 4 weeks followed by 2 weeks off, or a third arm combination of MM-398 $80 \mathrm{mg} / \mathrm{m}^{2} \mathrm{IV}$ with 5 -FU $2,400 \mathrm{mg} / \mathrm{m}^{2}$ given over 46 hours with leucovorin $400 \mathrm{mg} / \mathrm{m}^{2}$ every 2 weeks. In this study liposomal irinotecan was used due to data showed better drug stability and sustained release in the tumor area compared to irinotecan. The primary end point of study was OS. Median OS was 6.1 months in the combination treatment arm compared with 4.2 month in the control arm of 5-FU and folinic acid alone (HR 0.67; $\mathrm{p}=0.012$ ). The median PFS was longer in liposomal irinotecan in combination with 5-FU compared to 5-FU and folinic acid alone arm (3.1 versus 1.5 months, HR0.56, $\mathrm{p}=0.0001$ ). The objective response rate was higher in combination arm compared to 5-FU and folinic acid alone arm (16\% versus $1 \%, \mathrm{p}<$ $0.001)$. On the other hand OS rates were similar in between liposomal irinotecan monotherapy arm and 5-FU and folinic acid alone (median OS 4.9 versus 4.2 months, respectively, HR 0.99, p= 0.942). This might be explained by higher toxicity rates in monotherapy arm due to higher doses of liposomal irinotecan $\left(120 \mathrm{mg} / \mathrm{m}^{2}\right.$ in single agent arm, $80 \mathrm{mg} /$ $\mathrm{m}^{2}$ in combination arm) used in the monotherapy arm. In combination arm most frequent grade $\geq 3$ toxicities were neutropenia (20\%), fatigue $(14 \%)$, diarrhea (13\%) and vomiting (11\%). ${ }^{40}$

Although the evidence does not exist, the gemcitabine based regimens might be choice of treatment as a second line therapy in patients who had received FOLFIRINOX as a front line setting. In patients who had failed after first line nab-paxlitaxel plus gemcitabine combination the data about the second line therapies were still deficient.

\section{CONCLUSION}

The overall prognosis associated with pancreatic cancer is still poor and the death rates are still risng in recent decades. Recent developments of cancer therapy showed that some combinations are significantly better than single-agent chemotherapy. Gemcitabine is the currently accepted standard treatment for pancreatic cancer and a reasonable choice for poor prognostic patients. Although, promising results favored combination treatment with gemcitabine in most of the phase II trials, phase III trials with gemcitabine in combination with cisplatin, oxaliplatin, capacitabine, pemetrexed, irinotecan, bevacizumab, aflibercept, axitinib and cetuximab failed to improve primary endpoint OS. In addition to, in the subgroup of patients with good performance status, median OS was improved in combination of gemcitabine with cisplatin or capacitabine significantly, thus gemcitabine plus capecitabine or gemcitabine plus cisplatin can be a practical regimen that may be considered as an alternative to single-agent gemcitabine for the treatment of advanced/metastatic pancreatic cancer patients with a good performance status.

In randomized trials both FOLFIRINOX and gemcitabine-nab-paclitaxel combinations significantly improved PFS, response rate and OS compared to gemcitabine alone arm. As a targeted agent erlotinib is the first and only agent that demostrate significant activity with gemcitabine combination in patients with metastatic pancreatic cancer. Other combination tretaments with targeted agents failed to show significant OS benefit. Gemcitabine plus erlotinib combination significantly prolonged OS only 10 days, and this low meaningful benefit was suffice to take approval from Food and Drug Administration (FDA) and European Medicine Agency (EMA) compared to gemcitabine alone arm. In second line setting, combination of 5-FU and oxaliplatin showed significant benefit after first line gemcitabine in a small clinical trial and can be considered as a treatment option in this setting. According to the current guidelines gemcitabine is still good option for patients with metastatic pan- 
International Journal of Hematology and Oncology

\begin{tabular}{|c|c|c|c|c|}
\hline Author names & $\begin{array}{l}\text { Number of } \\
\text { patients }\end{array}$ & Study design & $\begin{array}{l}\text { Primary } \\
\text { endpoint }\end{array}$ & Comment \\
\hline \multicolumn{5}{|c|}{ Phase III studies that meet the primary endpoint } \\
\hline Burris, et al. ${ }^{3}$ & 126 & $\begin{array}{l}\text { Gemcitabine } \\
\text { 5-FU }\end{array}$ & CBR & $\begin{array}{l}\text { CBR; } 23.8 \% \text { vs } 4.8 \%(p=0.0022) \\
\text { PFS; } 2.33 \text { vs } 0.92 \text { months ( } p=0.002) \\
\text { OS; } 5.65 \text { vs } 4.41 \text { months }(p=0.0025)\end{array}$ \\
\hline Conroy, et al..$^{21}$ & 342 & $\begin{array}{l}\text { FOLFIRINOX } \\
\text { Gemcitabine }\end{array}$ & OS & $\begin{array}{l}\text { OS; } 11.1 \text { vs } 6.8 \text { months }(p<0.001) \\
\text { PFS; } 5.5 \text { VS } 3.7 \text { months }(p<0.001) \\
\text { ORR; } 31.6 \% \text { vs } \% 9.4(p<0.001)\end{array}$ \\
\hline Van Hoff, et al..$^{18}$ & 861 & $\begin{array}{l}\text { Gemcitabine+ } \\
\text { Nab-paclitaxel } \\
\text { Gemcitabine }\end{array}$ & OS & $\begin{array}{l}\text { OS; } 8.5 \text { VS } 6.7 \text { months }(p<0.001) \\
\text { PFS; } 6.4 \text { vs } 3.3 \text { months }(p<0.001) \\
\text { ORR; 23.0 VS 7.0\% }(p<0.001)\end{array}$ \\
\hline Moore, et al. ${ }^{28}$ & 569 & $\begin{array}{l}\text { Gemcitabine + } \\
\text { erlotinib vs Gemcitabine }\end{array}$ & OS & $\begin{array}{l}\text { OS; } 6.24 \text { vs } 5.91 \text { months }(p=0.038) \\
\text { PFS; } 3.75 \text { vs } 3.55 \text { months }(p=0.004) \\
\text { ORR; } 8.6 \% \text { vs } 8.0 \% \text { (Not significant) }\end{array}$ \\
\hline \multicolumn{5}{|c|}{ Phase III studies that did not meet the primary endpoint } \\
\hline Colucci, et al. ${ }^{7}$ & 107 & $\begin{array}{l}\text { Gemcitabine } \\
\text { Gemcitabine + Cisplatin }\end{array}$ & TTP, CBR & $\begin{array}{l}\text { OS; } 20 \text { vs } 30 \text { weeks }(p=0.48) \\
\text { TTP; } 8 \text { vs } 20 \text { weeks }(p=0.048) \\
\text { ORR; } 9.2 \% \text { vs } 26.4 \% \quad(p=0.02) \\
\text { No CBR benefit }\end{array}$ \\
\hline Heinemann, et al. ${ }^{8}$ & 195 & $\begin{array}{l}\text { Gemcitabine + Cisplatin } \\
\text { Gemcitabine }\end{array}$ & OS & $\begin{array}{l}\text { OS; } 7.5 \text { vs } 6.0 \text { months }(p=0.15) \\
\text { PFS; } 3.1 \text { vs } 35.3 \text { months }(p=0.053) \\
\text { ORR; (Not significant) }\end{array}$ \\
\hline Colucci et al. ${ }^{9}$ & 400 & $\begin{array}{l}\text { Gemcitabine + Cisplatin } \\
\text { Gemcitabine }\end{array}$ & OS & $\begin{array}{l}\text { OS; } 7.2 \text { vs } 8.3 \text { months }(p=0.80) \\
\text { PFS; } 3.8 \text { vs } 3.9 \text { months }(p=0.38) \\
\text { ORR; } 12.9 \text { vs } 10.1 \% \quad(p=0.37)\end{array}$ \\
\hline Herrmann, et al. ${ }^{14}$ & 319 & $\begin{array}{l}\text { Gemcitabine + Capecitabine } \\
\text { Gemcitabine }\end{array}$ & OS & $\begin{array}{l}\text { OS; } 8.4 \text { vs } 7.23 \text { months }(p=0.23) \\
\text { PFS; } 4.3 \text { vs } 3.9 \text { months }(p=0.103)\end{array}$ \\
\hline Cunningham, et al. ${ }^{15}$ & 533 & $\begin{array}{l}\text { Gemcitabine + Capecitabine } \\
\text { Gemcitabine }\end{array}$ & OS & $\begin{array}{l}\text { OS; } 7.1 \text { vs } 6.2 \text { months }(p=0.08) \\
\text { PFS; } 5.3 \text { vs } 3.8 \text { months }(p=0.004) \\
\text { ORR; } 19.1 \% \text { vs } 12.4 \%(p=0.034)\end{array}$ \\
\hline Louvet, et al. ${ }^{11}$ & 313 & $\begin{array}{l}\text { Gemcitabine +Oxaliplatin } \\
\text { Gemcitabine }\end{array}$ & OS & $\begin{array}{l}\text { OS; } 9.0 \text { vs } 7.0 \text { months }(p=0.13) \\
\text { PFS; } 5.8 \text { vs } 3.7 \text { months }(p=0.04) \\
\text { ORR; } 26.8 \% \text { vs } 17.3 \%(p=0.04)\end{array}$ \\
\hline Poplin, et al. ${ }^{13}$ & 832 & $\begin{array}{l}\text { Gemcitabine +Oxaliplatin } \\
\text { Gemcitabine FDR } \\
\text { Gemcitabine standard }\end{array}$ & OS & OS; 5.7 vs, 6.2 vs 4.9 months (not significant) \\
\hline Rocha Lima, et al. ${ }^{22}$ & 342 & $\begin{array}{l}\text { Gemcitabine +irinotecan } \\
\text { Gemcitabine }\end{array}$ & OS & $\begin{array}{l}\text { OS; } 6.3 \text { vs } 6.6 \text { months }(p=0.789) \\
\text { PFS; } 3.5 \text { vs } 3.0 \text { months }(p=0.352) \\
\text { ORR; } 16.1 \% \text { vs } 4.4 \%(p<0.001)\end{array}$ \\
\hline Oettle, et al. ${ }^{26}$ & 565 & $\begin{array}{l}\text { Gemcitabine + pemetrexed } \\
\text { Gemcitabine }\end{array}$ & OS & $\begin{array}{l}\text { OS; } 6.2 \text { vs } 6.3 \text { months }(p=0.847) \\
\text { PFS; } 3.9 \text { vs } 3.3 \text { months }(p=0.110) \\
\text { ORR; } 14.8 \% \text { vs } 7.1 \%(p=0.004)\end{array}$ \\
\hline \multicolumn{5}{|c|}{ Phase III studies that did not meet the primary endpoint with gemcibatine plus targeted agent combinations } \\
\hline Philip et, al. ${ }^{29}$ & 565 & $\begin{array}{l}\text { Gemcitabine + Cetuximab } \\
\text { Gemcitabine }\end{array}$ & OS & $\begin{array}{l}\text { OS; } 6.3 \text { vs } 5.9 \text { months ( } p=0.19 \text { ) } \\
\text { PFS; } 3.4 \text { vs } 3.0 \text { months ( } p=0.18 \text { ) } \\
\text { ORR; } 8.0 \text { vs } 7.0 \% \text { (not significant) }\end{array}$ \\
\hline Kindler et, al. ${ }^{30}$ & 602 & $\begin{array}{l}\text { Gemcitabine + Bevacizumab } \\
\text { Gemcitabine }\end{array}$ & OS & $\begin{array}{l}\text { OS; } 5.8 \text { vs } 5.9 \text { months ( } p=0.95 \text { ) } \\
\text { PFS; } 3.8 \text { vs } 2.9 \text { months ( } p=0.07 \text { ) } \\
\text { ORR; } 13.0 \% \text { vs } 10 \% \text { (not significant) }\end{array}$ \\
\hline
\end{tabular}


International Journal of Hematology and Oncology

Table 1 (Contineu). Selected phase III trials in the treatment of locally advancer or metastatic pancreatic cancer.

\begin{tabular}{|c|c|c|c|c|}
\hline Author names & $\begin{array}{l}\text { Number of } \\
\text { patients }\end{array}$ & Study design & Primary endpoint & Comment \\
\hline Rouiger, et al. ${ }^{32}$ & 546 & $\begin{array}{l}\text { Gemcitabine + aflibercept } \\
\text { Gemcitabine }\end{array}$ & OS & $\begin{array}{l}\text { OS; } 6.5 \text { vs } 7.8 \text { months ( } p=0.203 \text { ) } \\
\text { PFS; } 3.7 \text { vs } 3.7 \text { months }(p=1.0) \\
\text { (was stopped for futility following a planned } \\
\text { interim analysis of OS) }\end{array}$ \\
\hline Kindler, at al. ${ }^{31}$ & 632 & $\begin{array}{l}\text { Gemcitabine + axitinib } \\
\text { Gemcitabine }\end{array}$ & OS & $\begin{array}{l}\text { OS; } 8.5 \text { vs } 8.3 \text { months }(p=0.54) \\
\text { PFS; } 4.4 \text { vs } 4.4 \text { months }(p=0.52) \\
\text { ORR; } 12.0 \% \text { vs } 4.0 \%(p=0.018)\end{array}$ \\
\hline
\end{tabular}

Abbreviations: $\mathrm{CBR}=$ clinical benefit rate; FOLFIRINOX= Fluorouracil, leucovorin, irinotecan, oxaliplatin;

$\mathrm{ORR}=$ objective response rate; $\mathrm{OS}=$ overall survival; $\mathrm{PFS}=$ progression free survival; $T \mathrm{TP}=$ time to progression

creatic cancer especially for patients with poor prognosis and FOLFIRINOX, gemcitabine plus nab-paclitaxel or erlotinib combinations recommended in the first line treatment in patients with good performance. ${ }^{41,42}$

Although some combination regimens showed significant OS benefit compared to single-agent gemcitabine, the median OS was still less than 1 year. Despite the triple drug combinations, ORR did not exceed $35 \%$. On these grounds, future directions are needed to integrate new targeted agents and combination protocols for metastatic pancreatic cancer.

\section{REFERENCES}

1. Siegel RL, Miller KD, Jemal A. Cancer statistics, 2015. CA Cancer J Clin 65: 5-29, 2015.

2. Tajiri $\mathrm{H}$, Yoshimori M, Okazaki N, Miyaji M. Phase II study of continuous venous infusion of 5 -fluorouracil in advanced pancreatic cancer. Oncology 48: 18-21, 1991.

3. Burris HA, 3rd, Moore MJ, Andersen J, et al. Improvements in survival and clinical benefit with gemcitabine as first-line therapy for patients with advanced pancreas cancer: a randomized trial. J Clin Oncol 15: 2403-2413, 1997.

4. Burris $\mathrm{H}$, Storniolo AM. Assessing clinical benefit in the treatment of pancreas cancer: gemcitabine compared to 5-fluorouracil. Eur J Cancer 1997; 33 Suppl 1: S18-22, 1997.

5. Okusaka T, Funakoshi A, Furuse J, et al. A late phase II study of S-1 for metastatic pancreatic cancer. Cancer Chemother Pharmacol 61: 615-621, 2008.

6. Ueno H, loka T, Ikeda M, et al. Randomized phase III study of gemcitabine plus S-1, S-1 alone, or gemcitabine alone in patients with locally advanced and metastatic pancreatic cancer in Japan and Taiwan: GEST study. J Clin Oncol 31: 1640-1648, 2013.
7. Colucci G, Giuliani F, Gebbia V, et al. Gemcitabine alone or with cisplatin for the treatment of patients with locally advanced and/or metastatic pancreatic carcinoma: a prospective, randomized phase III study of the Gruppo Oncologia dell'Italia Meridionale. Cancer 94: 902-910, 2002.

8. Heinemann V, Quietzsch D, Gieseler F, et al. Randomized phase III trial of gemcitabine plus cisplatin compared with gemcitabine alone in advanced pancreatic cancer. J Clin Oncol 24: 3946-3952, 2006.

9. Colucci G, Labianca R, Di Costanzo F, et al. Randomized phase III trial of gemcitabine plus cisplatin compared with single-agent gemcitabine as first-line treatment of patients with advanced pancreatic cancer: the GIP-1 study. J Clin Oncol 28: 1645-1651, 2010.

10. Oliver G, Sugar E, Laheru D, Diaz L. Family history of cancer and sensitivity to platinum chemotherapy in pancreatic adenocarcinoma. 2010 Gastrointestinal Cancers Symposium; Abstract No. 151, 2010.

11. Louvet C, Andre T, Lledo G, et al. Gemcitabine combined with oxaliplatin in advanced pancreatic adenocarcinoma: final results of a GERCOR multicenter phase II study. J Clin Oncol 20: 1512-1518, 2002.

12. Louvet C, Labianca R, Hammel P, et al. Gemcitabine in combination with oxaliplatin compared with gemcitabine alone in locally advanced or metastatic pancreatic cancer: results of a GERCOR and GISCAD phase III trial. J Clin Oncol 23: 3509$3516,2005$.

13. Poplin E, Feng Y, Berlin J, et al. Phase III, randomized study of gemcitabine and oxaliplatin versus gemcitabine (fixed-dose rate infusion) compared with gemcitabine (30-minute infusion) in patients with pancreatic carcinoma E6201: a trial of the Eastern Cooperative Oncology Group. J Clin Oncol 27: 3778-3785, 2009.

14. Herrmann R, Bodoky G, Ruhstaller T, et al. Gemcitabine plus capecitabine compared with gemcitabine alone in advanced pancreatic cancer: a randomized, multicenter, phase III trial of the Swiss Group for Clinical Cancer Research and the Central European Cooperative Oncology Group. J Clin Oncol 25: 2212-2217, 2007. 
15. Cunningham D, Chau I, Stocken DD, et al. Phase III randomized comparison of gemcitabine versus gemcitabine plus capecitabine in patients with advanced pancreatic cancer. J Clin Oncol 27: 5513-5518, 2009.

16. Frese KK, Neesse A, Cook N, et al. nab-Paclitaxel potentiates gemcitabine activity by reducing cytidine deaminase levels in a mouse model of pancreatic cancer. Cancer Discov 2: 260269, 2012.

17. Von Hoff DD, Ramanathan RK, Borad MJ, et al. Gemcitabine plus nab-paclitaxel is an active regimen in patients with advanced pancreatic cancer: a phase I/II trial. J Clin Oncol 29: 4548-4554, 2011

18. Von Hoff DD, Ervin T, Arena FP, et al. Increased survival in pancreatic cancer with nab-paclitaxel plus gemcitabine. N Eng J Med 369: 1691-1703, 2013.

19. Ychou M, Conroy T, Seitz JF, et al. An open phase I study assessing the feasibility of the triple combination: oxaliplatin plus irinotecan plus leucovorin/ 5-fluorouracil every 2 weeks in patients with advanced solid tumors. Ann Oncology 14: 481-489, 2003.

20. Conroy T, Paillot B, Francois E, et al. Irinotecan plus oxaliplatin and leucovorin-modulated fluorouracil in advanced pancreatic cancer--a Groupe Tumeurs Digestives of the Federation Nationale des Centres de Lutte Contre le Cancer study. J Clin Oncol 23: 1228-1236, 2005.

21. Conroy T, Desseigne F, Ychou M, et al. FOLFIRINOX versus gemcitabine for metastatic pancreatic cancer. $N$ Engl J Med 364: 1817-1825, 2011.

22. Rocha Lima CM, Green MR, Rotche R, et al. Irinotecan plus gemcitabine results in no survival advantage compared with gemcitabine monotherapy in patients with locally advanced or metastatic pancreatic cancer despite increased tumor response rate. J Clin Oncol 22: 3776-83, 2004.

23. Stathopoulos GP, Syrigos K, Aravantinos G, et al. A multicenter phase III trial comparing irinotecan-gemcitabine (IG) with gemcitabine $(G)$ monotherapy as first-line treatment in patients with locally advanced or metastatic pancreatic cancer. $\mathrm{Br} J$ Cancer 95: 587-592, 2006.

24. Miller KD, Picus J, Blanke C, et al. Phase II study of the multitargeted antifolate LY231514 (ALIMTA, MTA, pemetrexed disodium) in patients with advanced pancreatic cancer. Ann Oncol 11: 101-103, 2000.

25. Adjei AA, Erlichman C, Sloan JA, et al. Phase I and pharmacologic study of sequences of gemcitabine and the multitargeted antifolate agent in patients with advanced solid tumors. J Clin Oncol 18: 1748-1757, 2000.

26. Oettle H, Richards D, Ramanathan RK, et al. A phase III trial of pemetrexed plus gemcitabine versus gemcitabine in patients with unresectable or metastatic pancreatic cancer. Ann Oncology 16: 1639-1645, 2005.

27. Ng SS, Tsao MS, Nicklee T, Hedley DW. Effects of the epidermal growth factor receptor inhibitor OSI-774, Tarceva, on downstream signaling pathways and apoptosis in human pancreatic adenocarcinoma. Mol Cancer Ther 1: 777-783, 2002.

28. Moore MJ, Goldstein D, Hamm J, et al. Erlotinib plus gemcitabine compared with gemcitabine alone in patients with advanced pancreatic cancer: a phase III trial of the National Cancer Institute of Canada Clinical Trials Group. J Clin Oncol 25: 1960-1966, 2007.

29. Philip PA, Benedetti J, Corless CL, et al. Phase III study comparing gemcitabine plus cetuximab versus gemcitabine in patients with advanced pancreatic adenocarcinoma: Southwest Oncology Group-directed intergroup trial S0205. J Clin Oncol 28: 3605-3610, 2010.

30. Kindler HL, Niedzwiecki D, Hollis D, et al. Gemcitabine plus bevacizumab compared with gemcitabine plus placebo in patients with advanced pancreatic cancer: phase III trial of the Cancer and Leukemia Group B (CALGB 80303). J Clin Oncol 28: 3617-3622, 2010.

31. Kindler HL, loka T, Richel DJ, et al. Axitinib plus gemcitabine versus placebo plus gemcitabine in patients with advanced pancreatic adenocarcinoma: a double-blind randomised phase 3 study. Lancet Oncol 12: 256-262, 2011.

32. Rougier $\mathrm{P}$, Riess $\mathrm{H}$, Manges $\mathrm{R}$, et al. Randomised, placebocontrolled, double-blind, parallel-group phase III study evaluating aflibercept in patients receiving first-line treatment with gemcitabine for metastatic pancreatic cancer. Eur $\mathrm{J}$ Cancer 49: 2633-2642, 2013

33. Androulakis N, Syrigos K, Polyzos A, et al. Oxaliplatin for pretreated patients with advanced or metastatic pancreatic cancer: a multicenter phase II study. Cancer Invest 23: 9-12, 2005.

34. Pelzer U, Schwaner I, Stieler J, et al. Best supportive care (BSC) versus oxaliplatin, folinic acid and 5 -fluorouracil (OFF) plus BSC in patients for second-line advanced pancreatic cancer: a phase III-study from the German CONKO-study group. Eur J Cancer 47: 1676-1681, 2011.

35. Oettle H, Riess H, Stieler JM, et al. Second-line oxaliplatin, folinic acid, and fluorouracil versus folinic acid and fluorouracil alone for gemcitabine-refractory pancreatic cancer: outcomes from the CONKO-003 trial. J Clin Oncol 32: 24232429, 2014

36. Gill S KY, Cripps C, Beaudoin A, et al. A randomized phase 3 study of 5FU/LV with or without oxaliplatin for second-line advanced pancreatic cancer (APC) in patients (pts) who have received gemcitabine (GEM)-based chemotherapy (CT). J Clin Oncol 32:5s, (suppl; abstr 4022), 2014.

37. Boeck S, Weigang-Kohler K, Fuchs M, et al. Second-line chemotherapy with pemetrexed after gemcitabine failure in patients with advanced pancreatic cancer: a multicenter phase II trial. Ann Oncol 18: 745-751, 2007.

38. Oettle H, Arnold D, Esser M, Huhn D, Riess H. Paclitaxel as weekly second-line therapy in patients with advanced pancreatic carcinoma. Anticancer Drugs 11: 635-638, 2000. 
International Journal of Hematology and Oncology

39. Boeck S, Wilkowski R, Bruns CJ, et al. Oral capecitabine in gemcitabine-pretreated patients with advanced pancreatic cancer. Oncology 73: 221-227, 2007.

40. Chen LTHD, Von Hoff DD, Li CP, et al. Expanded analyses of napoli-1: Phase 3 study of MM-398 (nal-IRI), with or without 5-fluorouracil and leucovorin, versus 5-fluorouracil and leucovorin, in metastatic pancreatic cancer (mPAC) previously treated with gemcitabine-based therapy. J Clin Oncol 33, (suppl 3; abstr 234) 2015.

41. Tempero MA, Malafa MP, Behrman SW, et al. Pancreatic adenocarcinoma, version 2.2014: featured updates to the NCCN guidelines. J Natl Compr Canc Netw 12: 1083-1093, 2014.

42. Seufferlein T, Bachet JB, Van Cutsem E, Rougier P, Group EGW. Pancreatic adenocarcinoma: ESMO-ESDO Clinical Practice Guidelines for diagnosis, treatment and follow-up. Ann Oncol 2012; 23 Suppl 7: vii33-40.

\section{Correspondence}

Dr. Mehmet Ali Nahit ŞENDUR

Yıldırım Beyazıt Üniversitesi

Tıp Fakültesi

Tıbbi Onkolojisi Bölümü

Bilkent

ANKARA / TURKEY

Tel: (+90-312) 2912525

e-mail: masendur@yahoo.com.tr 